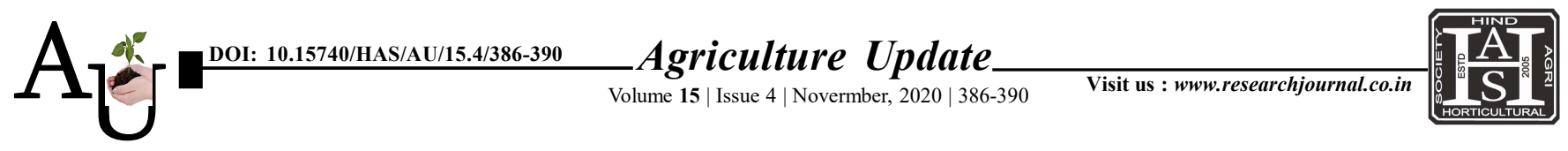

ISSN-0973-1520

\title{
Research Article: An assessment of constraints faced by sesame growing farmers in Kerala
}

S. Sreepriya and T. Girija

Article Chronicle :

Received :

15.02.2020;

Revised:

03.10.2020;

Accepted :

$22 . .10 .2020$

Key Words : Constraints, Sesame farmers, Survey, Garrett ranking 2020: Hind Agri-Horticultural Society.
SUMMARY : Identification of constraints and providing timely suggestions are important for sesame farmers in Kerala as the state has been witnessing a declining trend of the crop production. The study is concerned with the constraints faced by sesame growing farmers in Kerala. A field survey was conducted in three districts of Kerala viz., Alappuzha Kollam and Thrissur. Respondents included 30 farmers from each district. Garrett Ranking technique was used to rank the constraints faced in sesame production. As per the survey, high labour cost, excessive rain, drought, weed infestation, labour unavailability, pest and diseases, marketing problem, transportation, drying and threshing problem and storage problem were the constraints identified in the decreasing order of rank. Suggestions and methods to overcome the constraints were also provided.

How to cite this article : Sreepriya, S. and Girija, T. (2020). An assessment of constraints faced by sesame growing farmers in Kerala. Agric. Update, 15(4): 386-390; DOI : 10.15740/HAS/AU/15.4/386-390. Copyright@
Author for correspondence :

\section{S. Sreepriya}

Department of Plant Physiology, College of Agriculture, Kerala Agricultural University, Vellanikkara, Thrissur (Kerala) India

Email: sreepriyasanthosh 88@gmail.com

See end of the article for authors' affiliations 